\title{
Efektivitas Penerapan Model Pembelajaran Reciprocal Teaching dalam Meningkatkan Kemampuan Komunikasi Matematis Siswa
}

\author{
Nasruddin*1, Jahring ${ }^{2}$ \\ 1,2, Universitas Sembilanbelas November Kolaka \\ e-mail: * ${ }^{1}$ nash.matematika@gmail.com, ${ }^{2}$ jahring.usn@gmail.com
}

\begin{abstract}
Abstrak
Jenis penelitian ini adalah Penelitian Tindakan Kelas (PTK) penelitian true eksperimen dengan design yang bertujuan untuk Meningkatkan Kemampuan Komunikasi Matematis Siswa. Populasi penelitian adalah seluruh siswa kelas X Farmasi di SMK Negeri 1 Watunohu. Penelitian ini diawali dengan kegiatan observasi kemudian memberikan tes awal dan kemudian melakukan pelaksanaan PTK dalam dua siklus tindakan. Teknik pengambilan data yang menggambarkan pelaksanaan pembelajaran dengan lembar observasi sedangkan data yang menggambarkan kemampuan komunikasi matematis siswa didapat melalui tes tindakan penelitian melalui instrument soal tiap siklus. Hasil penelitian ini menujukkan bahwa kemampuan komunikasi matematis siswa dapat ditingkatkan melalui model pembelajaran Reciprocal Teaching. Hal ini ditunjukkan oleh hasil yang diperoleh dari tes awal bahwa tidak ada siswa yang memperoleh predikat sangat baik,namun yang dikategorikan baik sebanyak $13.33 \%$ sedangkan yang dikategorikan cukup baik sekitar 33.33\%, dan yang dikategorikan kurang baik sebanyak $53.33 \%$. Pada hasil tes siklus I meningkat, yang memperoleh nilai sangat baik sebanyak $6.67 \%$, komunikasi matematis siswa yang dikategorikan baik sebanyak $53.33 \%$, sedangkan dikaategorikan cukup baik sebanyak 6.67\%. Pada tes siklus II mengalami meningkat, siswa memperoleh sangat baik sebanyak 13.33\%, memperoleh predikat baik sebanyak $80 \%$, sedangkan yang dikategorikan cukup baik 33.33\%, dan yang dikategorikan kurang baik $6.67 \%$. Dengan demikian indikator keberhasilan dalam penelitian tindakan kelas ini dapat tercapai dengan baik.
\end{abstract}

Kata kunci-Reciprocal teaching, PTK, hasil belajar

\section{PENDAHULUAN}

Matematika merupakan salah satu mata pelajaran yang banyak digunakan pada mata pelajaran lainnya, misalnya fisika, kimia, biologi, ekonomi, dan ilmu pengetahuan lainnya. Banyak siswa yang mengalami kesulitan dalam belajar matematika. Siswa beranggapan bahwa matematika adalah pelajaran yang sulit dan memerlukan suatu pemikiran yang keras dan otak yang cerdas. Anggapan ini menyebabkan mereka patah semangat dalam belajar. Mereka enggan mencoba dan lebih suka mengatakan tidak bisa sebelum mencoba mengerjakan soal yang diberikan guru sehingga cenderung pasif. Salah satu penyebabnya adalah sifat objek matematika yang abstrak. Sifat tersebut dapat menyebabkan matematika sulit dipahami.

National Council of Teachers of Mathematics (NCTM) (Putri, 2011), menyatakan bahwa pembelajaran matematika di sekolah dari jenjang pendidikan dasar hingga kelas XII memerlukan standar pembelajaran yang berfungsi untuk menghasilkan siswa yang memiliki 
kemampuan berpikir, kemampuan penalaran matematis, memiliki pengetahuan serta keterampilan dasar yang bermanfaat. Proses pembelajaran dapat kita artikan sebagai sebuah kegiatan yang di dalamnya terjadi penyampaian materi pembelajaran dari seorang tenaga pendidik kepada para peserta didik yang dimilikinya. Budaya yang makin mensejahterakan manusia tersebut tidak jarang memerlukan sumber pendudung (Nasruddin, 2017). Salah satu dari standar proses pembelajaran adalah komunikasi (communication). Komunikasi dalam hal ini tidak sekedar komunikasi secara lisan atau verbal tetapi juga komunikasi secara tertulis. Komunikasi secara lisan dan tertulis termuat dalam komunikasi matematis. Komunikasi matematis adalah kemampuan siswa untuk menyatakan ide-ide matematika baik secara lisan maupun tertulis. Irianto (Sumarno, 2012), Menyatakan ide-ide matematika secara lisan dalam hal ini adalah komunikasi yang bersifat konvergen, artinya komunikasi yang berlangsung secara multi arah dari beberapa penerima informasi (siswa) menuju satu pemahaman materi yang dipahami bersama yang berlangsung secara dinamis serta berkembang ke arah pemahaman kolektif dan berkesinambungan.

Berdasarkan wawancara dan hasil pengamatan di lapangan, peneliti memperoleh informasi bahwa kemampuan siswa dalam berkomunikasi matematis masih jauh dari apa yang diharapakan. Salah satu penyebabnya adalah gaya guru dalam mengajar. Guru lebih memfokuskan pada konsep-konsep matematika. Di dalam kelas, guru biasanya memulai proses pembelajaran dengan menjelaskan konsep matematika, memberikan contoh bagaimana mengerjakan soal yang sejenis dengan soal yang sudah diterangkan oleh guru. Sehingga siswa kurang menanggapi apa yang telah diberikan oleh guru dan masih kurang siswa yang termotivasi untuk belajar matematika, enggan untuk mengerjakan soal latihan, tugas atau PR, serta siswa jarang memiliki keberanian untuk bertanya di kelas oleh karena itu perlu memilih metode pembelajaran yang tepat dan siswa dapat lebih aktif.

Untuk mengatasi permasalahan diatas, diperlukan suatu model pemeblajaran yang sifatnya dapat mendorong siswa agar bias lebih aktif di kelas. Salah satu model pembelajaran yang dapat digunakan adalah model pembelajaran Reciprocal Teaching. Menurut Palincsar (Zein, 2013), bahwa strategi Reciprocal Teaching adalah pendekatan konstruktivis yang didasarkan pada prinsip-prinsip membuat pertanyaan, mengajarkan ketrampilan metakognitif melalui pengajaran, dan pemodelan oleh guru untuk meningkatkan ketrampilan membaca pada siswa yang berkemampuan rendah. Reciprocal Teaching juga merupakan strategi belajar melalui kegiatan mengajarkan teman. Pada strategi ini siswa berperan sebagai guru, menggantikan guru untuk mengajarkan teman-temannya Menurut Ibrahim (Hayati, 2009), Reciprocal Teaching adalah model pembelajaran berupa kegiatan mengajarkan materi kepada teman. Pada model pembelajaran ini siswa berperan sebagai guru untuk menyampaikan materi kepada teman-temannya. Sementara itu guru lebih berperan sebagai fasilitator dan pembimbing yang melakukan scaffolding. Scaffolding adalah bimbingan yang diberikan oleh orang yang lebih tahu kepada orang kurang tahu atau belum tahu (Bandhi, 2009).

Reciprocal Teaching adalah model pembelajaran berupa kegiatan mengajarkan materi kepada teman. Pada model pembelajaran ini siswa berperan sebagai guru untuk menyampaikan materi kepada teman-temannya. Sementara itu guru lebih berperan sebagai fasilitator dan pembimbing yang melakukan scaffolding. Scaffolding adalah bimbingan yang diberikan oleh orang yang lebih tahu kepada orang kurang tahu atau belum tahu Ibrahim (Hayati, 2009). Belajar dengan menggunakan pendekatan Reciprocal Teaching juga dapat mendorong siswa kelas X SMKN 1 Watunohu untuk membangun keterampilan-keterampilan itu sendiri dengan memberikan rangsangan, dukungan, dan sarana-sarana yang mendukung.

SAINTIFIK Vol. 5, No. 1, Januari 2019: 27-35 


\section{METODE PENELITIAN}

Jenis penelitian yang digunakan dalam penelitian ini adalah Penelitian Tindakan Kelas (PTK) yang dilakukan secara kolaboratif dan partisipatif. Kolaboratif artinya peneliti berkolaborasi atau bekerja sama dengan guru kelas $\mathrm{X}$ sebagai praktisi dan teman sejawat sebagai pengamat. Sedangkan partisipatif artinya peneliti berpartisipasi dalam pembelajaran. Tindakan yang direncanakan berupa Peningkatan komunikasi matematis siswa melalui penerapan model pembelajaran Reciprocal Teaching.

Penelitian ini dilaksanakan di SMK Negeri 1Watunohu pada kelas X semester ganjil tahun pelajaran 2018/2019.

Model Penelitian Tindakan Kelas (PTK) memiliki beberapa tahapan, dalam satu siklus terdiri atas empat tahapan, keempat tahapan tersebut, meliputi : (1) perencanaan (planning), (2) pelaksanaan (acting), (3) pengamatan (observing), dan (4) refleksi (reflecting). Sesudah suatu siklus selesai di implementasikan, khususnya sesudah adanya refleksi, kemudian diikuti dengan adanya perencanaan ulang yang dilaksanakan dalam bentuk siklus tersendiri.

Teknik Pengumpulan data yang digunakan dalam penelitian ini adalah melakukan observasi, dokumentasi, dan tes. Adapun instrument yang digunakan selama penelitian adalah peneliti, lembar observasi, dan tes hasil kemampuan komunikasi matematis siswa.

Berdasarkan ketentuan dan keadaan siswa di sekolah tempat penelitian ini, yang disesuaikan pula dengan kurikulum yang digunakan tersebut maka indikator keberhasilan dalam penelitian ini adalah 1) jika Rata-rata hasil kemampuan komunikasi matematis siswa mengalami peningkatan dilihat dari tindakan pelaksanaan penelitian; 2) Ketuntasan hasil kemampuan komunikasi matematis secara klasikal tuntas. Hasil kemampuan komunikasi matematis dikatakan tuntas secara klasikal individual jika $80 \%$ dari jumlah siswa yang mengikuti proses pembelajaran memperoleh nilai $\geq 60$; dan 3) Dari segi proses pembelajaran dikatakan berhasil jika $80 \%$ skenario pembelajaran telah terlaksana/ dilaksanakan.

\section{HASIL DAN PEMBAHASAN}

\subsection{Hasil Penelitian}

Dari observasi dan evaluasi awal yang dilakukan oleh peneliti ini bertujuan untuk mengetahui kemampuan awal siswa dalam memahami materi trigonometri, maka diperoleh hasil kemampuan komunikasi matematis siswa seperti yang disajikan pada tabel 1 berikut:

Tabel 1 Hasil Tes Awal

\begin{tabular}{|l|r|}
\hline Mean & 37.00 \\
\hline Median & 33.00 \\
\hline Std. Deviation & 21.827 \\
\hline Variance & 476,428 \\
\hline Minimum & .00 \\
\hline Maximum & 75.00 \\
\hline
\end{tabular}

Dari tabel 1 tampak bahwa hasil kemampuan komunikasi matematis siswa setelah dilaksanakan tes awal tergolong rendah. Berdasarkan kriteria penilaian kemampuan komunikasi matematis apabila siswa memperoleh nilai 80-100 dikategorikan sangat baik, 60-79 dikatakan baik, 40-59 dikatakan cukup baik, dan jika meperoleh nilai 0-39 dikategorikan kurang baik. Pada hasil evaluasi awal tidak ada siswa yang memperoleh predikat sangat baik, komunikasi matematis siswa yang dikategorikan baik sebanyak $13.33 \%$, sedangkan yang dikategorikan 
cukup baik sekitar 33.33\%, dan yang dikategorikan kurang baik sebnyak 53.33\%. Sehingga dapat di simpulkan bahwa hasil evaluasi awal kemampuan komunikasi matematis siswa kelas X F SMK Negeri 1 Watunohu hanya sebanyak $13.33 \%$ yang berarti bahwa hanya terdapat 2 orang siswa memiliki nilai yang memenuhi syarat kemampuan komunikasi matematis secara klasikal.

Selanjutnya berdasarkan hasil tes pelaksanaan tindakan siklus I, diperoleh bahwa hasil kemampuan komunikasi matematis siswa sedikit mengalami peningkatan dari hasil tes awal. Perhatikan statistik deskriptif hasil tes siklus I seperti yang diuraikan dalam tabel 2 berikut:

Tabel 2 Hasil Tes Siklus I

\begin{tabular}{|l|r|}
\hline Mean & 61.20 \\
\hline Median & 67 \\
\hline Std. Deviation & 15.603 \\
\hline Variance & 243.4571 \\
\hline Minimum & 25.00 \\
\hline Maximum & 83.00 \\
\hline
\end{tabular}

Dari tabel dan histogram di atas, terlihat bahwa hasil kemampuan komunikasi matematis siswa yang telah diajar setelah pelaksanaan tes tindakan siklus I memiliki perbedaan yaitu mengalami peningkatan yang cukup baik bila dibandingkan tes awal secara rata-rata mengalami peningkatan yaitu 61,2 sedangkan rata-rata pada tes awal hanya mencapai 37 . Begitu pula komunikasi matematis tiap siswa mengalami peningkatan cukup baik.

Berdasarkan kriteria penilaian kemampuan komunikasi matematis apabila siswa memperoleh nilai 80-100 dikategorikan sangat baik, 60-79 dikatakan baik, 40-59 dikatakan cukup baik, dan jika meperoleh nilai 0-39 dikategorikan kurang baik. Pada hasil evaluasi tindakan siklus I siswa yang memperoleh predikat sangat baik sebanyak $6.67 \%$, komunikasi matematis siswa yang dikategorikan baik sebanyak 53.33\%, sedangkan dikategorikan cukup baik sekitar 33.33\%, dan yang dikategorikan cukup baik sebanyak 6.67\%. Namun hal ini belum mencapai indikator keberhasilan yang telah ditetapkan sebelumnya. Sehingga penelitian ini dilanjutkan lagi pada tahap siklus berikutnya yakni siklus II.

Berdasarkan hasil tes pelaksanaan tindakan siklus II, diperoleh bahwa hasil kemampuan komunikasi matematis siswa mengalami peningkatan dari hasil tes tindakan siklus I. Perhatikan hasil tes siklus II seperti yang telah diuraikan dalam tabel 3 berikut:

Tabel 3 Hasil Tes Siklus II

\begin{tabular}{|l|c|}
\hline Mean & 72.87 \\
\hline Median & 75 \\
\hline Std. Deviation & 7.989 \\
\hline Variance & 63.838 \\
\hline Minimum & 58.00 \\
\hline Maximum & 92.00 \\
\hline
\end{tabular}

Dari tabel 3 di atas, terlihat bahwa hasil kemampuan komunikasi matematis siswa yang telah diajar setelah pelaksanaan tes tindakan siklus II memiliki perbedaan yaitu mengalami peningkatan yang cukup baik bila dibandingkan tes tindakan siklus I secara rata-rata mengalami peningkatan yaitu 72,87 sedangkan rata-rata pada tes tindakan siklus I hanya mencapai 61. Begitu pula kemampuan komunikasi matematis tiap siswa mengalami peningkatan cukup baik.

Berdasarkan kriteria penilaian kemampuan komunikasi matematis apabila siswa memperoleh nilai 80-100 dikategorikan sangat baik, 60-79 dikatakan baik, 40-59 dikatakan 
cukup baik, dan jika meperoleh nilai 0-39 dikategorikan kurang baik. Pada hasil evaluasi tindakan siklus II siswa yang memperoleh predikat sangat baik sebanyak 13.33\%, yang memperoleh predikat baik cukup banyak yakni mencapai $80 \%$, sedangkan yang dikategorikan cukup baik sekitar 33.33\%, dan yang dikategorikan kurang baik sebanyak 6.67\%. Sehingga dapat disimpulkan bahwa menunjukkan hasil kemampuan komunikasi matematis siswa mengalami peningkatan sebesar 33,33\% dibanding hasil tes siklus I. siswa yang memperoleh nilai $\geq 60$ sebanyak 14 orang siswa atau dengan kata lain kemampuan komunikasi matematis sudah baik dari 15 siswa dengan persentase keberhasilan 93,33\% dengan nilai rata-rata 72,87.

Hal ini berarti bahwa hasil tes tindakan siklus II sudah sangat tinggi atau dapat dikatakan telah memenuhi indikator keberhasilan yang telah ditetapkan.

\subsection{Pembahasan}

Penelitian ini dilaksanakan sesuai yang telah direncanakan sebelumnya yaitu dilaksanakan sebanyak dua siklus. Setiap siklus dilakukan tiga kali pertemuan, sehingga penelitian ini terhitung sebanyak enam kali pertemuan dimana tiap siklus terdiri dari dua kali pertemuan pembahasan materi dan satu kali pertemuan tes siklus.

Dari hasil evaluasi awal, tes tindakan I dan II menunjukkan bahwa ketuntasan belajar siswa secara klasikal mengalami peningkatan dari nilai rata-rata yaitu tes kemampuan awal hanya 2 orang siswa dari 15 orang siswa mampu memperoleh nilai $\geq 60$ atau sebesar $13.33 \%$ dengan rata-rata sebesar 37,5. Pada siklus I, terlihat hasil kemampuan komunikasi matematis siswa dapat meningkat terdapat 9 orang siswa dari 15 orang siswa telah memperoleh nilai $\geq 60$ atau sebesar $60 \%$ dengan rata-rata sebesar 61,2 . Hal ini menunjukkan peningkatan sebesar 46,67\% dari tes awal. Rendahnya hasil kemampuan komunikasi matematis ini disebabkan karena beberapa hal, salah satunya karena siswa masih merasa baru dan belum terbiasa dengan penerapan skenario pembelajaran yang diterapkan oleh guru sehingga siswa merasa ragu untuk mengemukakan pendapatnya dan malu untuk bertanya atau mengeluarkan pendapatnya saat dalam kesulitan. Hal ini berarti bahwa penelitian dilanjutkan pada pelaksanaan tindakan siklus II.

Pada pelaksanaan siklus II, sudah nampak adanya peningkatan hasil kemampuan komunikasi matematis siswa yang signifikan. Hal ini dapat terlihat perolehan hasil kemampuan komunikasi matematis siswa yaitu terdapat 14 orang siswa dari 15 orang siswa yang dapat memperoleh nilai $\geq 60$ atau sebesar 93,33\% dengan nilai rata-rata sebesar 72,87 dengan kata lain meningkat $33,33 \%$ dari tes siklus I. hal ini berarti bahwa indikator keberhasilan hasil kemampuan komunikasi matematis yang telah ditentukan sudah tercapai yaitu $80 \%$. Peningkatan rata-rata hasil tes awal, tes tindakan I dan tes tindakan II dapat dilihat pada gambar diagram berikut: 


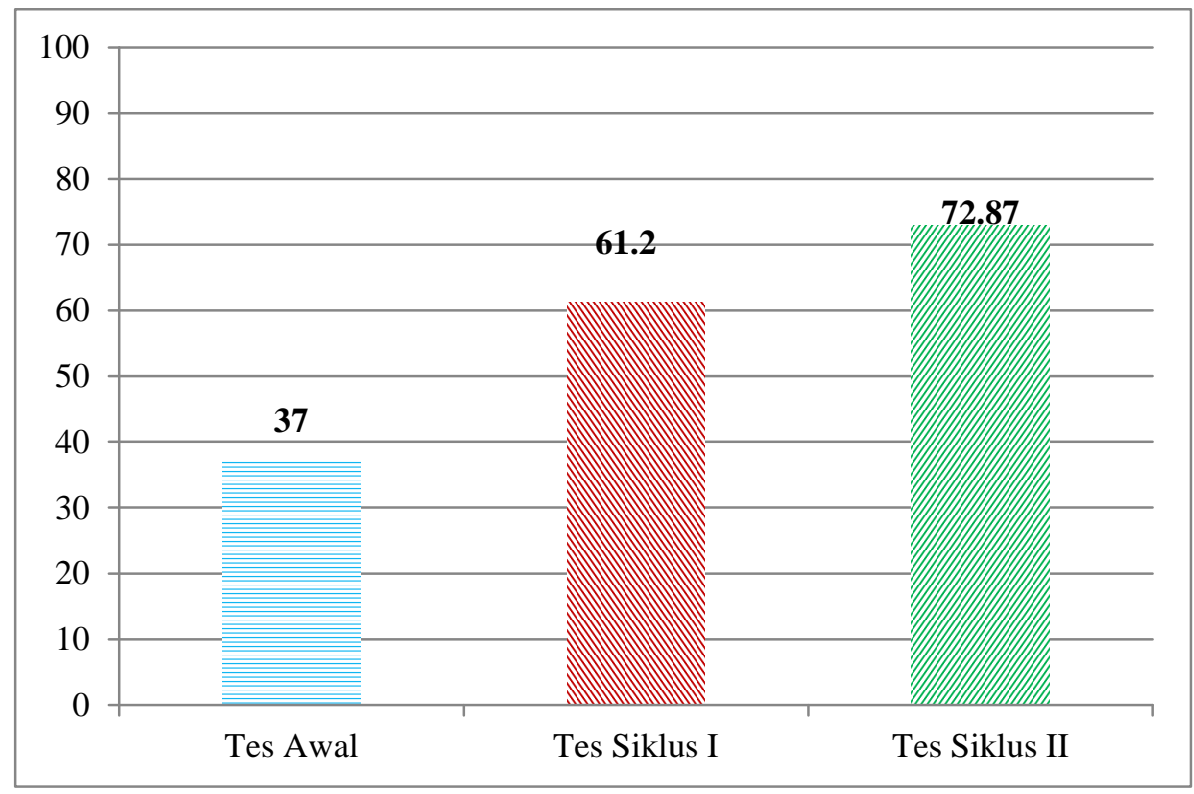

Gambar 1 Peningkatan Rata-rata Kemampuan Komunikasi Matematis

Untuk melihat peningkatan hasil kemampuan komunikasi matematis pada statistik deskriptif yang ada pada tes awal, siklus I dan siklus II dengan jelas perhatikan tabel 4 . berikut:

Tabel 4 Statstik Deskriptif Kemampuan Komunikasi Matematis

\begin{tabular}{|l|c|c|c|}
\hline \multicolumn{1}{|c|}{ Kategori } & Tes Awal & Tes Siklus I & Tes Siklus II \\
\hline Rata-Rata & 37 & 61,2 & 72,87 \\
\hline Standar Deviasi & 21,827 & 15,603 & 7,989 \\
\hline Varians & 476,428 & 243,457 & 63,838 \\
\hline Maximal & 75 & 83 & 92 \\
\hline Minimal & 0 & 25 & 58 \\
\hline $\begin{array}{l}\text { Persentase } \\
\text { Keberhasilan }\end{array}$ & $13.33 \%$ & $60 \%$ & $93.33 \%$ \\
\hline
\end{tabular}

Karena indikator keberhasilan dalam penelitian ini telah tercapai dengan baik yaitu minimal $80 \%$ siswa telah mencapai $\geq 60$ sesuai nilai Kriteria Komunikasi Matematis yang telah ditetapkan sebelumnya, dengan demikian hipotesis tindakan pada penelitian ini telah terjawab atau telah tercapai yaitu "dengan penerapan model pembelajaran Reciprocal Teaching dapat meningkatkan kemampuan komunikasi matematis siswa Kelas X MTs SMK Negeri 1 Watunohu.

Hasil observasi guru pada pelaksanaan siklus I pertemuan pertama sebesar $75 \%$. dan pada pertemuan dua sebesar $80 \%$. Namun belum mencapai indikator keberhasilan, tapi sudah mengalami peningkatan 5\%. Kekurangan yang dilakukan oleh guru selama proses pembelajaran berlangsung diantaranya adalah kurangnya motivasi yang diberikan oleh guru kepada siswa, sehingga ada beberapa tahapan kegiatan pembelajaran yang terlangkahi karena pengalokasian waktu kurang tepat. Melihat adanya kekurangan selama proses pembelajaran berlangsung pada siklus I masih belum memenuhi indikator keberhasilan yang telah ditetapkan, maka penelitian ini dilanjutkan pada tindakan siklus II. Pada siklus II hasil observasi pada aktivitas guru mengalami peningkatan dimana pada pertemuan pertama sebesar $95 \%$. Pada pertemuan kedua 
sebesar $100 \%$. Jadi, pada pertemuan kedua telah memenuhi indikator keberhasilan. Berikut tabel persentasi hasil observasi aktivitas guru:

Tabel 5 Tabel Hasil Observasi Aktivitas Guru

\begin{tabular}{|c|c|c|}
\hline & Siklus I & Siklus II \\
\hline Pertemuan I & $75 \%$ & $95 \%$ \\
\hline Pertemuan II & $80 \%$ & $100 \%$ \\
\hline Rata-Rata & $77,5 \%$ & $97,5 \%$ \\
\hline
\end{tabular}

Hasil observasi aktivitas siswa pada siklus I pertemuan pertama sebesar $63 \%$ terdapat pada lampiran 19 pada pertemuan kedua sebesar $76 \%$. Hal ini belum mencapai ketuntasan namun telah mengalami peningkatan $13 \%$. Kekurangan-kekurangan yang terdapat pada siklus I tersebut diantaranya adalah masih banyak siswa yang tidak memperhatikan penjelasan guru, kurangnya keberanian siswa untuk mengemukakan pendapat atau mengajukan pertanyaan ketika menemukan masalah dalam LKS serta siswa kurang termotivasi untuk mempersentasikan hasil diskusi kelompoknya. Pada tindakan siklus II, peneliti sebagai guru bersama dengan guru mitra berusaha memperbaiki kekurangan-kekurangan yang terdapat pada siklus I, sehingga sedikit demi sedikit kekurangan-kekurangan tersebut mulai diperbaiki. Pada tindakan siklus II, partisipasi aktif siswa dalam kegiatan pembelajaran terlihat pada hasil observasi yang telah mengalami peningkatan dimana pada pertemuan pertama yaitu $83 \%$ dan pada pertemuan kedua sebesar $93 \%$ jadi pada siklus II nampak bahwa aktivitas belajar siswa telah meningkat. Berikut hasil observasi aktivitas siswa:

Tabel 6 Tabel Hasil Observasi Aktivitas Siswa

\begin{tabular}{|c|c|c|}
\hline & Siklus I & Siklus II \\
\hline Pertemuan I & $63 \%$ & $83 \%$ \\
\hline Pertemuan II & $76 \%$ & $93 \%$ \\
\hline Rata-Rata & $67,5 \%$ & $88 \%$ \\
\hline
\end{tabular}

Berdasarkan hasil dari evaluasi dan observasi yang telah dilakukan oleh peneliti terhadap hasil kemampuan komunikasi matematis dan proses pembelajaran dengan menerapkan pembelajaran Reciprocal teaching telah mencapai indikator yang telah di tentukan. Karena kedua indikator tersebut telah tercapai maka hasil kemampuan komunikasi matematis siswa kelas X F SMK Negeri 1 Watunohu pada materi Trigonometri dapat ditingkatkan.

\section{KESIMPULAN}

Berdasarkan hasil penelitian dan pembahasan yang telah dipaparkan. Maka dapat disimpulksn bahwa:

1. Aktivitas mengajar guru mengalami peningkatan dengan persentase siklus I pertemuan pertama sebesar $75 \%$ pada pertemuan kedua sebesar $80 \%$ dari skor maksimal $100 \%$. Hal ini

Efektivitas Penerapan Model Pembelajaran Reciprocal Teaching dalam Meningkatkan 
telah mengalami peningkatan namun namun belum mencapai indikator keberhasilan, persentase siklus II pada pertemuan pertama sebesar 95\% dan pada pertemuan kedua $100 \%$ dari skor maksimal 100\%. Hal ini telah mencapai indikator keberhasilan yang telah ditentukan dalam penelitian ini yakni $80 \%$

2. Aktivitas belajar siswa mengalami peningkatan dengan persentase siklus I pertemuan pertama sebesar $63 \%$ pada pertemuan kedua $76 \%$ dari skor maksimal $100 \%$. Hal ini telah mengalami peningkatan namun belum mencapai indikator keberhasilan. Persentase pada siklus II pertemuan pertama $83 \%$ dan pertemuan kedua sebesar $93 \%$ dari skor maksimal $100 \%$. Hal ini telah mencapai indikator keberhasilan yang telah ditentukan dalam penelitian sebesar $80 \%$

3. Dengan meningkatkan aktivitas mengajar guru dan aktivitas belajar siswa membawa dampak positif pada kemampuan komunikasi matematis siswa yang dicapai siswa kelas X F SMK Negeri 1 Watunohu, yaitu pada tindakan siklus I diperoleh bahwa kemampuan komunikasi matematis siswa secara klasikal sebesar $60 \%$ atau sebanyak 9 orang siswa dari 15 orang siswa yang memperoleh nilai $\geq 60$ dengan nilai rata-rata 61,2 dan hasil tes siklus II kemampuan komunikasi matematis siswa secara klasikal sebesar 93,33\% atau sebanyak 14 orang siswa dari 15 siswa yang memperoleh nilai $\geq 60$ dengan rata-rata 72,87 . Dari hasil tes siklus I dan siklus II menunjukkan bahwa kemampuan komunikasi matematis pada siswa kelas X F SMK Negeri 1 Watunohu pada materi perbandingan trigonometri dengan menerapkan pendekatan pembelajaran reciprocal teaching dapat ditingkatkan.

\section{DAFTAR PUSTAKA}

Ansari, Bansu Irianto. 2003. Menumbuhkembangkan Kemampuan Pemahaman Dan Komunikasi Matematik Siswa SMU Melalui Strategi Think-Talk-Write (Studi Eksperimen Pada Siswa Kelas I SMU N di Kota Bandung). Bandung : Disertasi UPI.

Arikunto, Suharsimi. 2015. Dasar-dasar Evaluasi Pendidikan. Jakarta: Bumi Askara

Bandhi, Aji. 2009. Upaya Meningkatkan Kemampuan Komunikasi Matematika Siswa Dalam Pembelajaran Matematika Melalui Model Pembelajaran Kooperatif Tipe Teams Games Tournament (TGT) Siswa Kelas VIII-D SMP Negeri 2 Sleman. Yogyakarta : SKRIPSI UNY.

Erman Suherman, dkk. 2001. Strategi Pembelajaran Matematika Kontemporer. Bandung : JICA Universitas Pendidikan Indonesia (UPI).

Hayati, Indri Nur. (2009). Implementasi Pembelajaran Dengan Pendekatan Reciprocal Teaching Sebagai Upaya Meningkatkan Kemandirian Belajar Matematika Dan Hasil kemampuan komunikasi matematis Matematika Untuk Pokok Bahasan Kesebangunan Pada Siswa Kelas IX-I SMP Negeri 1 Pacitan. [Online]. Tersedia : $\underline{\text { Http://Eprints.Uny.Ac.Id/1896/ }}$ [30 Desember 2017].

Nasruddin dan Abidin, Z. 2017. Meningkatkan Hasil Belajar Matematika Melalui Model Pembelajaran Kooperatif Tipe Jigsaw pada Siswa SMP. Journal of Educational Science and Technology. ISSN: 2460-1497, Vol.3. No. 2 Hal. 113-121.

Putri, Runtyani Irjayanti. (2011). Upaya Meningkatkan Kemampuan Komunikasi Matematis Siswa Dalam Pembelajaran Matematika Melalui Pendekatan Reciprocal Teaching Dengan Model Pembelajaran Kooperatif Di Kelas VIII-D SMP Negeri 4 Magelang. [Online]. Tersedia : Http://Eprints.Uny.Ac.Id/2181/1/Skipsi Runtyani. Ip.Pdf [30 Desember 2017].

Suderadjat, Hari. 2004. Implementasi Kurikulum Berbasis Kompetensi (KBK). Bandung : Cipta Cekas Grafika.

Sumarmo, Utari. (2012). Pendidikan Karakter serta Pengembangan Berfikir dan Disposisi Matematik dalam Pembelajaran Matematika. Makalah pada Seminar Pendidikan Matematika di NTT. [Online]. Tersedia: http://utarisumarmo. 
dosen.stkipsiliwangi.ac.id/files/2015/09/Makalah-Univ-di-NTTFebruari-2012.pdf (diakses pada tanggal 25 September 2016)..

Zaeni, Ahmad. (2013). Pengaruh Model Pembelajaran Reciprocal Teaching Terhadap Kemampuan Berpikir Kreatif Matematika Siswa Kelas VIII SMP Negeri 8 Cirebon. [Online]. Tersedia : Http://Repository.Syekhnurjati.Ac.Id/1418/1/Ahmad Zaeni_Ok.Pdf [2 Januari 2018]. 